\title{
PENGEMBANGAN INSTRUMEN PENILAIAN PEMBELAJARAN DI SMA IBRAHIMY WONGSRSEREJO BANYUWANGI
}

\author{
Junaidi \& Taufiqurrahman \\ Universitas Ibrahimy Situbondo, Indonesia \\ Universitas Ibrahimy Situbondo, Indonesia \\ joens_07@yahoo.com \\ taufiqurrahman.info@gmail.com
}

\begin{abstract}
Assessment is a critical factor for successful learning. Assessment is part of instructional design system. Assessment and learning are related as cycles that occur before, during and after learning; diagnostic, formative and summative. Effective learning embodies a variety of appropriate and consistent assessments. This outreach involved all teachers at SMA Ibrahimy Wongsorejo, Banyuwangi as part of the Salafiyah Syafi'iyah Islamic Boarding School in Sukorejo, Situbondo. This ability is the most important ability in learning evaluation. From that assessment a teacher can know the abilities that have been mastered by the students. Teachers must know basic competencies (KD) that have been mastered by the students. The teacher makes a self-reflection from the activities that have been done. To get the expected target, it is necessary to instill four awareness for the teachers. They are sense of goal (goal), sense of regulation (regularity), sense of achievement (achievement), and Sense of harmony (harmony). The process of mentoring at SMA Ibrahimy Wongsorejo was conducted in several stages: initial mapping, building relationships with school members, participatory mapping, agenda setting, implementation, and reflection. This outreach process can transform knowledge and practice
\end{abstract}

Keywords: Instrument Penilaian, Pembelajaran, Pengabdian 


\section{Pendahuluan}

Implementasi kurikulum berbasis kompetensi membawa implikasi terhadap model dan teknik penilaian yang dilaksanakan di kelas. Penilaian pembelajaran terdiri atas penilaian eksternal (external assessment) dan penilaian internal (internal assessment). Penilaian eksternal merupakan penilaian yang dilakukan oleh pihak lain yang tidak melaksanakan proses pembelajaran. Penilaian eksternal dilakukan oleh suatu lembaga, baik dalam maupun luar negeri yang dimaksudkan antara lain untuk pengendali mutu. Sedangkan penilaian internal adalah penilaian yang direncanakan dan dilakukan oleh guru pada proses pembelajaran berlangsung dalam rangka penjaminan mutu. Dengan demikian, penilaian kelas merupakan penilaian internal.

Penilaian kelas merupakan penilaian internal (internal assessment) terhadap proses dan hasil belajar peserta didik yang dilakukan oleh guru di kelas atas nama sekolah untuk menilai kompetensi peserta didik pada tingkat tertentu pada saat dan akhir pembelajaran. Kurikulum berbasis kompetensi menuntut model dan cara penilaian dengan Penilaian Kelas sehingga dapat diketahui perkembangan dan ketercapaian berbagai kompetensi peserta didik

Langkah terpadu penilaian-pembelajaran itu adalah: menggunakan data penilaian sumatif untuk menyusun tujuan 
pembelajaran; mengungkapkan kriteria dan model di awal pembelajaran; melakukan penilaian sebelum pem- belajaran; menawarkan metode belajar dan penilaian yang relevan; memberikan umpan balik yang tepat, spesifik, dapat dimengerti dan mampu diikuti siswa; mendorong siswa untuk melakukan penilaian diri dan penetapan target belajar; dan terbuka terhadap kriteria atau bukti baru untuk menentukan keberhasilan belajar siswa. Praktik penilaian tidak terbatas pada penggunaan penilaian respon terstruktur, misalnya dalam bentuk pilihan ganda, menjodohkan, benar salah; ataupun instrumen penilaian sikap yang berlaku secara nasional, bebas konteks dan lokalitas. Penilaian melibatkan semua aktor dan terjadi dalam setiap bagian pembelajar- an sebagai sistem. Aktor utama penilaian adalah guru dan siswa sebagai avant garde praktik penilaian, aktor pendukung adalah kepala sekolah, guru BP dan administrator sekolah.Setiap aktor berperan dalam mem- bangun profil belajar siswa.Aktor utama berperan penting dalam fasilitasi pencapaian kompetensi yang ditetapkan.

Pola atau langkah-langkah peman- faatan hasil penilaian ditentukan oleh pendekatan pembelajaran yang dianut.Pendekatan teacher-centered menggunakan penilaian sebagai instrumen untuk mengukur hasil belajar siswa.Penentuan ketuntasan belajar siswa 
menggunakan bentuk-bentuk penilaian obyektif dan terukur, serta mengadaptasi metode kerja ilmu-ilmu positivistik dalam desain penilaian.Data-data yang didokumen-tasikan berupa angka-angka, ditampilkan dalam bentuk tabel atau grafik dalam pelaporan capaian belajar siswa.Penilaian tradisional ini menawarkan hasil yang obyektif, dapat digeneralisasikan, dan ditafsirkan menurut hukum-hukum yang adekuat. Pendekatan penilaian yang dikem- bangkan dari bidang psikologi Behaviorisme (Kratochwill \& Bijou, 2013) ini tidak terbebas dari proses reduksi, baik pada tahap perancangan, pelaksanaan dan pelaporan. Dimensi keterukuran akan mereduksi aspek- aspek yang 'tidak dapat diukur'; analisis statistik berpotensi mereduksi keutuhan konsep yang diukur, misalnya pilihan antara validitas isi dan validitas statistik; generalisasi mengandaikan keseragaman setiap individu dalam populasi.

Pendekatan pembelajaran yang berpusat kepada siswa (student centered) menempatkan siswa sebagai subyek pembelajaran. Pendekatan ini, pada dasarnya, bertujuan untuk mengembangkan otonomi dan kemandirian siswa dengan cara mem-berikan tanggungjawab belajar pada siswa. Dengan demikian, siswa harus memahami tentang struktur kurikulum yang akan di-tempuh dan mampu mengelola proses belajarnya (Jahnke, 2012). Pendekatan pem-belajaran ini diarahkan pada 
kompetensi penyelesaian masalah secara mandiri dan belajar sepanjang hayat (lifelong learning).Hal tersebut didasarkan pada teori belajar konstruktivis (Keengwe \& Onchwari, 2016) yang menekankan pada peran siswa dalam mem- bangun pengetahuan baru melalui penataan informasi yang dimiliki dan pengalamannya. Perbedaan kritis antara teacher centered dan student centered adalah penilaian. Pendekatan pertama lebih menekankan penilaian suma- tif, sedangkan kedua menekankan penilaian formatif (Curly 2014). Dalam pembelajaran student centered, siswa berperanserta dalam menilai belajarnya. Penilaian dikembangkan untuk meningkatkan proses pembelajaran dan mengembangkan motivasi siswa.

Pergeseran pendekatan pembelajaran dalam Sistem Pendidikan Nasional, dengan demikian, tidak hanya pada penetapan dan sosialisasi model-model pembelajaran yang relevan semata, tetapi saling-topang antara pembelajaran dan penilaian sebagai sistem inti; serta pengelolaan sebagai sistem pendu- kung. Pergeseran pendekatan pembelajaran seharusnya diikuti secara relatif serentak pada tiga bidang tersebut.Sejarah pembelajaran di Indonesia menekankan secara berurutan pada tiga aspek tersebut.Penerapan manajemen berbasis sekolah menekankan desentralisasi pengelolaan dan mendorong pembelajaran kurikulum muatan lokal, scientific approach dalam 
pembelajaran dirancang untuk memperbaiki metode pembelajaran, penilaian autentik diterapkan untuk dapat memperoleh pemahaman tentang siswa secara lebih mendalam.Rangkaian sejarah pembelajaran tersebut belum terangkai secara kokoh untuk menampilkan profil pembelajaran yang mantap.Peningkatan pembelajaran setahap-demisetahap (inkrimental) sebagai sistem ditantang inertia atau keengganan aktor pembelajaran, adaptasi pengelolaan dan perubahan aspek eksternal.

Implementasi Kurikulum 2013, untuk semua tingkat satuan pendidikan berimplikasi pada proses penilaian pencapaian kompetensi peserta didik. Penilaian pencapaian kompetensi oleh pendidik dilakukan untuk memantau proses, kemajuan, perkembangan pencapaian kompetensi peserta didik sesuai dengan potensi yang dimiliki dan kemampuan yang diharapkan secara berkesinambungan. Penilaian juga dapat memberikan umpan balik kepada pendidik agar dapat menyempurnakan perencanaan dan proses pembelajaran (Peraturan Menteri Pendidikan dan Kebudayaan No. 66 Tahun 2013 tentang Standar Penilaian Pendidikan).

Data yang diperoleh pendidik selama pembelajaran berlangsung dijaring dan dikumpulkan melalui prosedur dan alat penilaian yang sesuai dengan kompetensi atau indikator yang akan dinilai. Melalui 
proses tersebut, diperoleh potret/profil kemampuan peserta didik dalam mencapai sejumlah kompetensi inti dan kompetensi dasar yang dirumuskan dalam kurikulum masing-masing satuan pendidikan.

Penilaian oleh pendidik merupakan suatu proses yang dilakukan melalui langkah- langkah perencanaan, penyusunan alat penilaian, pengumpulan informasi melalui sejumlah bukti yang menunjukkan pencapaian kompetensi peserta didik, pengolahan, dan pemanfaatan informasi tentang pencapaian kompetensi peserta didik. Penilaian tersebut dilakukan melalui berbagai teknik/cara, seperti penilaian unjuk kerja (performance), penilaian sikap, penilaian tertulis (paper and pencil test), penilaian projek, penilaian produk, penilaian melalui kumpulan hasil kerja/karya peserta didik (portofolio), dan penilaian diri.

Keberhasilan implementasi kurikulum 2013, khususnya pada proses penilaian sangat tergantung pada guru, namun kenyataan di lapangan menunjukkan bahwa guru masih kesulitan dalam menyusun perencanaan penilaian, pelaksanaan penilaian, pengolahan hasil penilaian serta pemanfaatan hasil penilaian. Hal ini disebabkan terjadinya miskonsepsi guru terhadap pengertian, istilah, dan prosedur penilain yang tertuang dalam Peraturan Menteri Pendidikan dan Kebudayaan tentang penilaian.Salah satu penyebab terjadinya 
miskonsepsi ini adalah banyaknya informasi yang diperoleh guru dari sumber yang tidak jelas.

\section{Permasalahan}

Pembelajaran yang efektif ditentukan oleh penggunaan hasil penilaian dalam proses pembelajaran. Perencanaan pembelajaran, diagnosa tingkat keberhasilan belajar atau kesulitan belajar, perekaman hasil belajar siswa dan kualitas hasil belajar siswa membutuhkan datadata penilaian, baik data diagnostik, data proses maupun data sumatif siswa. Namun, praktik penilaian guru dilakukan dengan seharusnya. Penggunaan instrument penilaian yang disalin dari buku, berpotensi memberikan informasi yang salah tentang hasil belajar siswa, selain itu juga melanggar prinsip-prinsip praktik penilaian. Praktik demikian diasumsikan karena guru kurang mendapatkan latihan on site. Guru mendapatkan keterampilan penyusunan instrument melalui workshop singkat, dan pengawas mata pelajaran yang tidak terkelanjutan. Kondisi ini berdampak pada pengambilan keputusan tentang hasil belajar siswa yang tidak didasari oleh data-data yang akurat.

\section{Tujuan pendampingan}

Tujuan pendampingan pengembangan instrumen penilaian pembelajaran adalah : 
1. untuk memberdayakan potensi guru dalam menghasilkan data-data tentang hasil belajar siswa secara akurat dan guru dapat melakukan perbaikan dari data hasil penilaian.

2. Memberikan penjelasan mengenai orientasi baru penilaian dalam kurikulum berbasis kompetensi.

3. Memberikan wawasan secara umum tentang konsep penilaian hasil belajar yang dilaksanakan pada tingkat kelas oleh pendidik.

4. Memberikan rambu-rambu penilaian pembelajaran.

5. Memberikan prinsip-prinsip pengolahan dan pelaporan hasil penilaian.

\section{Signifikansi}

Kurikulum 2013 mengalami beberapa perkembangan dan perbaikan sejak digulirkannya pada tahun 2013. Perbaikan kurikulum tersebut berlandaskan pada kebijakan Landasan kebijakan Menteri Pendidikan dan Kebudayaan yang tertuang dalam Permendikbud Nomor 160 tahun 2014 tentang Pemberlakuan Kurikulum 2006 dan Kurikulum 2013.

Konsep kurikulum 2013 sangat baik sekali diterapkan di Negara Indonesia dimana sekarang ini terjadi degradasi moral dan mental. Masalah tersebut bisa di atasi hanya melalui pendidikan yang mengutamakan keseimbangan antara pendidikan sikap (social dan 
spiritual), pengetahuan dan keterampilan. Pendidikan di Indonesia yang lalu masih mengutamakan aspek pengetahuan saja, tanpa memperhatikan aspek pendidikan sikap dan keterampilan. Banyak anak bangsa ini cerdas secara pengetahuan tapi sepi dari sikap yang dan keterampilan yang handal. Sehingga kalau dibandingkan dengan bangsa lain kita masih tertinggal. Kurikulum 2013 merupakan kurikulum yang memberikan solusi bagi masalah yang sedang dihadapi.

Implementasi Kurikulum 2013 pada tahun 2013 menghadapi berbagai masalah, sehingga perlu adanya perbaikan. Berbagai masukan dari berbagai kalangan (masyarakat sipil, asosiasi profesi, perguruan tinggi, dunia persekolahan) terhadap ide, dokumen, dan implementasi kurikulum yang diperoleh melalui monitoring dan evaluasi dari berbagai media. Berdasarkan hasil monitoring dan evaluasi serta masukan publik tersebut, terdapat beberapa masukan umum, antara lain adanya pemahaman yang kurang tepat oleh masyarakat yang diakibatkan oleh format penyajian dan nomenklatur dalam Kurikulum 2013: (1) Kompetensi Dasar (KD) pada Kompetensi Inti 1 (KI-1) dan KD pada KI-2 yang dianggap kurang logis dikaitkan dengan karakteristik mata pelaajaran; (2) terindikasi adanya inkonsistensi antara KD dalam silabus dan buku teks (baik lingkup 
materi maupun urutannya); (3) belum ada pernyataan eksplisit dalam dokumen kurikulum tentang perlunya peserta didik lebih melek teknologi; (4) format penilaian dianggap terlalu rumit dan perlu penyederhanaan; (5) penegasan kembali pengertian pembelajaran saintifik yang bukan satu-satunya pendekatan dalam proses pembelajaran di kelas; (6) penyelerasan dan perbaikan teknis buku teks pelajaran agar mudah dipelajari oleh peserta didik.

Secara umum, perbaikan Kurikulum 2013 bertujuan agar selaras antara ide, desain, dokumen, dan pelaksanaannya. Secara khusus, perbaikan Kurikulum 2013 bertujuan menyelaraskan KI-KD, silabus, pedoman mata pelajaran, pembelajaran, penilaian, dan buku teks.

Tujuan utama dari pendampingan ini adalah untuk memberikan penguatan kepada guru sasaran mengenai kurikulum 2013 terutama dalam pembuatan rencana pelakasanaan pembelajaran, proses pembelajaran dan penilaian serta memastikan implementasi kurikulum 2013 ditingkat satuan pendidikan yang ditunjuk sudah dilaksanakan. Produk yang harus dihasilkan dari pendampingan ini adalah dokumen rencana pelaksanaan pembelajaran, hasil pengamatan proses pembelajaran dan hasil pengolahan penilaian.

Dokumen rencana pelaksanaan pembelajaran (RPP) merupakan rencana pembelajaran yang akan dilaksanakan dikelas harus disetorkan 
kepada instruktur sebagai pedoman untuk pengamatan proses pembelajaran. Pelaksanaan pembelajaran merupakan implementasi dari RPP, tetapi dalam pelaksanan kita harus melihat situsional dan kondisi yang sewaktu-waktu ada kendala. Tahapan pembelajaran antara lain :

Pada tahap pendahuluan, guru wajib mempersiapkan fisik dan psikis peserta didik, sehingga mereka siap untuk menerima materi pelajaran dari guru dengan menyenangkan. Salah satu cara yang bisa dilakukan adalah dengan memulai pembelajaran dengan berdoa, mengucapkan salam dan mengecek kehadiran peserta didik yang tidak masuk serta mendoakan peserta didik yang sakit. Aktifitas tersebut merupakan pembiasaan untuk internalisasi sikap social dan spiritual. Kebiasaan tersebut harus dilakukan oleh semua guru mata pelajaran. Namun kenyataannya sering ditemukan guru tidak berdoa ketika memulai dan mengakhiri pembelajaran.

Pendekatan penilaian dapat diklasifikasikan menjadi penilaian tradisional yang scientifik dan penilaian alternatif yang komprehensif.Kedua pendekatan ini tidak untuk dipertentangkan, namun dapat digunakan secara bersama-sama untuk mencapai tujuantujuan spesifik. Mueller (2006) menegaskan bahwa "But a teacher does not have to choose between Authentic Assessment and Traditional Assessment. It is likely thatsome mix of the two will best meet your need." Penilaian yang 
menekankan pada obyektivitas dan akurasi pengukuran sangat tepat mengaplikasikan pendekatan penilaian tradisional dan teori-teori yang mendasarinya untuk menghasilkan kualitas data penilaian yang dimaksud; sebaliknya penilaian untuk merekam aspek-aspek yang berkaitan dengan real-life siswa secara komprehensif didukung oleh pendekatan penilaian alternatif dan prosedur-presedur yang terkait.

Keberhasilan dalam mengaplikasikan berbagai pendekatan pembelajaran akan berdampak pada perbaikan pembelajaran dan pengambilan keputusan tentang hasil belajar siswa. Praktik penilaian yang mengedepankan pada peran aktif siswa, secara sistemik akan merangkai sub-sistem pembelajaran lainnya untuk meningkat, dan pada akhirnya, untuk mencapai tujuan pendidikan nasional secara realistis dan akurat.

\section{Kerangka Konsep}

\section{Gambaran Umum Lokasi Pendampingan}

SMA Ibrahimy wongsorejo didirikan pada tahun 1988.Sekolah yang beralamat di Jl. Bimo no. 1 ini dikepalai oleh Maswandi, S.Pd.I.Sekolah dekat dengan jalan raya, 10 meter masuk dari arah jalan raya ini memiliki bangunan yang sudah cukup berumur.Sekolah ini berdampingan dengan MTs Negeri Wongsorejo. Lokasi penelitian dapat 
dilihat pada peta berikut:

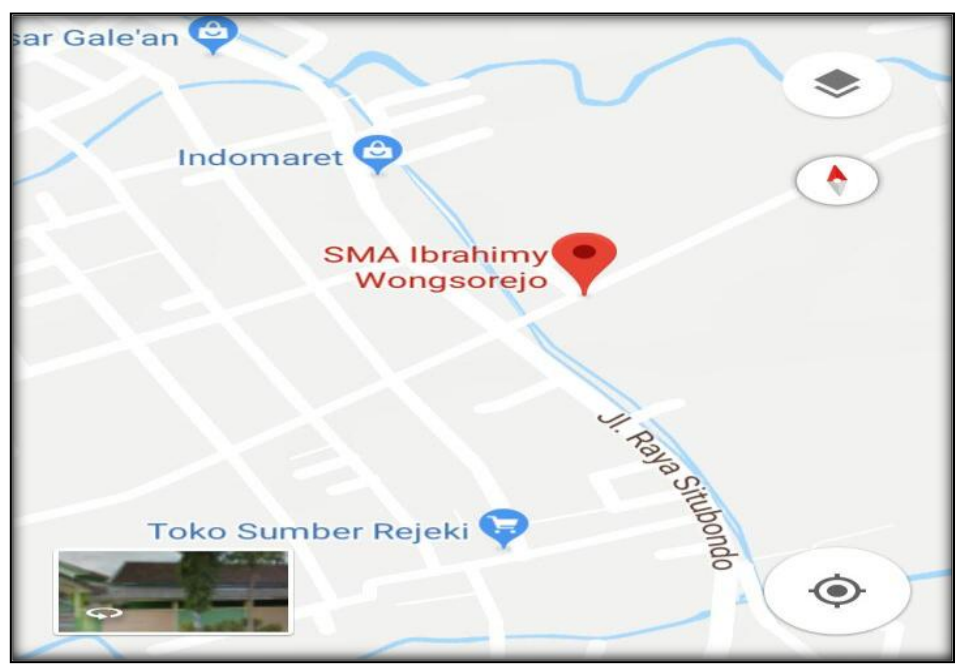

gambar 1. Peta lokasi dampingan.

\section{Kondisi Saat ini Masyarakat Dampingan}

Berdasarkan hasil observasi awal dan penyebaran angket yang dibagikan kepada guru sebagai pemetaan awal, didapatkan hasil bahwa 87 persen (20 dari 23 guru) mengalami kesulitan dalam memahami cara penilaian, 70 persen (16 dari 23 guru) kesulitan dalam pembuatan instrumen observasi, 66 persen (15 dari 23 guru) kesulitan dalam memahami model-model pembelajaran, dan 79 persen (18 dari 23 guru) mengalami kesulitan membuat instrumen penilaian. Ini artinya guru di sekolah, ini memang sangat membutuhkan pendampingan. 


\section{Kondisi yang diharapkan}

Setelah proses pendampingan pengembangan penilaian ini semua guru di SMA Ibrahimy wongsorejo Banyuwangi sebagai bagian dari lembaga binaan Pondok Pesantren Salafiyah Syafi'iyah Sukorejo Situbondo diharapkan mampu untuk menguasai kemampuan memberikan penilaian kepada peserta didiknya. Kemampuan ini adalah kemampuan terpenting dalam evaluasi pembelajaran. Dari penilaian itulah seorang guru dapat mengetahui kemampuan yang telah dikuasai oleh para peserta didiknya. Harus mengetahui kompetensi dasar (KD) apa saja yang telah dikuasai oleh peserta didik dan segera mengambil tindakan perbaikan ketika terjadi nilai peserta didiknya lemah atau kurang sesuai dengan harapan. Dari penilaian yang dilakukan oleh guru itulah, guru melakukan perenungan diri dari apa yang telah dilakukan. Setiap siswa adalah juara, dan guru harus mampu mengantarkan peserta didiknya menjadi seorang juara di bidangnya.

Untuk mendapatkan target yang diharapkan maka perlu ditanamkan empat kesadaran kepada guru adalah:

1) Sense of goal (tujuan)

2) Sense of regulation (keteraturan)

3) Sense of achievement (berprestasi)

4) Sense of harmony (keselarasan) 


\section{Strategi Pelaksanaan}

Pendampingan yang dilakukan menggunakan pendekatan partisipatif. Proses pendampingan tidak didominasi oleh aktor eksternal. Pendamping melibatkan secara aktif semua stakeholders dalam menemukan pokok masalah yang dihadapi, merancang tindakan yang akan dilakukan untuk merubah situasi menjadi lebih baik, menunjuk aktor-aktor local (sekolah) yang akan melakukan transformasi situasi saat ini menuju situasi yang lebih baik. Proses kerja yang dilakukan dasari prinsip empowerment atau pemberdayaan aktor-aktor sekolah. Langkah kerja pemberdayaan ini dijabarkan sebagai berikut:

\section{Pemetaan Awal}

Pemetaan awal digunakan sebagai alat untuk memahami sebuah komunitas, sehingga pendamping akan mudah memahami realitas problem dan relasi sosial yang terjadi. Dengan cara demikian akan memudahkan untuk masuk ke dalam komunitas sekolah baik melalui administrator sekolah maupun melalui relasi dengan stakeholder yang sudah terbangun. Pendamping akan melakukan pemetaan secara umum situasi sekolah yang akan diteliti, menentukan informan awal, dan mempersiapkan logistic pendampingan. 


\section{Membangun hubungan dengan sekolah}

Membangun hubungan ini pada dasarnya adalah membangun human relation, hubungan kemanuasiaan dengan segala subyektivitas, kepentingan dan harapan serta kepedulian. Tindakan ini merupakan sebuah inkulturasi dan membangun kepercayaan (Trust building) dengan masyarakat, sehingga terjalin hubungan yang setara dan saling mendukung. Pendamping dan masyarakat bisa menyatu menjadi sebuah simbiosis mutualisme untuk melakukan kajian, belajar memahami masalahnya, dan memecahkan persoalanya secara bersamasama (Partiisipatif).

\section{Menetukan agenda kegiatan awal}

Penentuan agenda awal merupakan metode untuk melibatkan masyarakat sekolah lebih lanjut untuk mendalami permasalahan yang dihadapi oleh sekolah. Pendamping memfasilitas dan membuka ruangruang diskusi yang mengarah pada penemuan masalah-masalah yang dihadapi (masyarakat) sekolah.

\section{Pemetaan partisipatif}

Keterlibatan masyarakat sekolah dalam penentuan agenda awal menghasilkan keprihatinan yang dihadapi secara parsial. Pada tahap ini, pendamping mengajak masyarakat sekolah untuk memetakan atau mengklasifikasi masalah yang dihadapi untuk menentukan masalah 
pokok yang akan dihadapi. Masalah disusun berdasarkan klasifikasi yang merujuk pada standar nasional pendidikan, dan diurut secara hirarkis berdasarkan nalar sebab-akibat.

\section{Merumuskan masalah pokok}

Masalah-masalah yang teridentifikasi dan dipetakan pada tahap sebelumnya, selanjutnya dikaji secara lebih komprehensif untuk menemukan satu pokok persoalan yang dihadapi oleh masyarakat sekolah. Salah satu teknik yang digunakan untuk menentukan masalah utama yang dihadapi adalah pohon masalah. Teknik ini memberikan tampilan masalah secara hirarkis dan diuji dengan nalar sebab-akibat. Penentuan masalah ini, sebisa mungkin melalui permufakatan, bila sulit dicapai akan diputuskan melalui proses suara mayoritas.

\section{Menyusun strategi kegiatan}

Pokok masalah yang ditemukan pada tahap sebelumnya merupakan kondisi negatif yang akan ditransformasikan menjadi situasi yang diharapkan. Teknik transformasi situasi ini adalah dengan melanjutkan menuliskan pernyataan positif yang disepakati sebagai penyelesaian masalah pokok. Penyelesaian ini kemudian dijabarkan melalui prasyarat-prasyarat yang dibutuhkan untuk mewujudkan kondisi yang diharapkan. Dalam memilih prasyarat kondisi tersebut memperhatikan sub pokok masalah yang telah dituliskan pada tahap sebelumnya. 
Dengan kata lain, pengembangan strategi tindakan secara detil adalah penyelesaian masalah-masalah spesifik sebagai prasyarat keberhasilan penyelesaian masalah pokok.

\section{Kajian Teori}

Penilaian kelas merupakan suatu kegiatan guru yang terkait dengan pengambilan keputusan tentang pencapaian kompetensi atau hasil belajar peserta didik yang mengikuti proses pembelajaran tertentu. Untuk itu, diperlukan data sebagai informasi yang diandalkan sebagai dasar pengambilan keputusan. Keputusan tersebut berhubungan dengan sudah atau belum berhasilnya peserta didik dalam mencapai suatu kompetensi. Jadi penilaian kelas merupakan salah satu pilar dalam pelaksanaan kurikulum berbasis kompetensi.

Data yang diperoleh guru selama pembelajaran berlangsung dapat dijaring dan dikumpulkan melalui prosedur dan alat penilaian yang sesuai dengan kompetensi atau hasil belajar yang akan dinilai. Oleh sebab itu, penilaian kelas lebih merupakan proses pengumpulan dan penggunaan informasi oleh guru untuk memberikan keputusan, dalam hal ini nilai terhadap hasil belajar peserta didik berdasarkan tahapan belajarnya. Dari proses ini, diperoleh potret/profil kemampuan peserta didik dalam mencapai sejumlah standar kompetensi dan kompetensi dasar yang tercantum dalam kurikulum 
Penilaian dipahami sebagai proses pengumpulan informasi tentang belajar siswa untuk meningkatkan pembelajaran. Walvoord menegaskan bahwa penilaian adalah "the systematic collection of information about student learning, using the time, knowledge, expertise, and resources available, in order to inform decision about how to improve learning"1. Penilaian menekankan pada hasil aktual (actual outcome) siswa, bukan pada hasil yang diharapkan (intended outcome), sebagaimana termaktub dalam tujuan pembelajaran. Penilaian merupakan sebentuk 'penelitian tindakan' untuk memberikan informasi kepada praktisi tentang indikator ketercapaian tujuan pembelajaran. Data yang diperoleh digunakan oleh guru untuk memperbaiki proses pembelajaran, dan oleh manajemen sekolah -bahkan Kementerian Pendidikan- untuk menilai pelaksanaan kurikulum.

Evaluasi adalah kegiatan identifikasi untuk melihat apakah suatu program yang telah direncanakan telah tercapai atau belum, berharga atau tidak, dan dapat pula untuk melihat tingkat efisiensi pelaksanaannya. Evaluasi berhubungan dengan keputusan nilai (value judgement). Stufflebeam yang dikutip (Abin Syamsuddin Makmun, 1996) mengemukakan bahwa : educational evaluation is the process of delineating,

1 Walvoord, B. E. Assessment clear and simple: A practical guide for institutions. San Francisco, (CA: John Wiley \& Sons. 2004), 2. 
obtaining, and providing useful, information for judging decision alternatif . Dari pandangan Stufflebeam, kita dapat melihat bahwa esensi dari evaluasi yakni memberikan informasi bagi kepentingan pengambilan keputusan. Di bidang pendidikan, kita dapat melakukan evaluasi terhadap kurikulum baru, suatu kebijakan pendidikan, sumber belajar tertentu, atau etos kerja guru.

Pengukuran (measurement) adalah proses pemberian angka atau usaha memperoleh deskripsi numerik dari suatu tingkatan di mana seorang peserta didik telah mencapai karakteristik tertentu. Dengan angka-anagka kita dapat mengetahui ketercapaian siswa dalam menguasai Standar Kompetensi yang sudah diajarkan.

Sedangkan penilaian (assessment) adalah penerapan berbagai cara dan penggunaan beragam alat penilaian untuk memperoleh informasi tentang sejauh mana hasil belajar peserta didik atau ketercapaian kompetensi (rangkaian kemampuan) peserta didik. Penilaian menjawab pertanyaan tentang sebaik apa hasil atau prestasi belajar seorang peserta didik. Hasil penilaian dapat berupa nilai kualitatif (pernyataan naratif dalam kata-kata) dan nilai kuantitatif (berupa angka). Pengukuran berhubungan dengan proses pencarian atau penentuan nilai kuantitatif tersebut. 
Tes adalah cara penilaian yang dirancang oleh guru, dan dilaksanakan kepada peserta didik pada waktu dan tempat tertentu serta dalam kondisi yang memenuhi syarat-syarat tertentu yang jelas. Sebaiknya tes dilakukan dengan cara menyenangkan sehingga hasilnya benar-benar sesuai dengan yang diharapkan.

Secara khusus, dalam konteks pembelajaran di kelas, penilaian dilakukan untuk mengetahui kemajuan dan hasil belajar peserta didik, mendiagnosa kesulitan belajar, memberikan umpan balik/perbaikan proses belajar mengajar, dan penentuan kenaikan kelas. Melalui penilaian dapat diperoleh informasi yang akurat tentang penyelenggaraan pembelajaran dan keberhasilan belajar peserta didik, guru, serta proses pembelajaran itu sendiri. Berdasarkan informasi itu, dapat dibuat keputusan tentang pembelajaran, kesulitan peserta didik dan upaya bimbingan yang diperlukan serta keberadaan kurikukulum itu sendiri.

Makna penilaian mencakup mencakup masukan, lingkungan, pengalaman belajar di sekolah dan keluaran pendidikan atau Standar Kompetensi Lulusan pada tingkat satuan pendidikan tertentu. Penilaian mencari jawaban tentang apa yang seharusnya siswa pelajari, kontribusi satuan pendidikan terhadap perkembangan siswa, dan metode 
pengembangan pembelajaran. Penilaian merupakan basis pengambilan keputusan.

Klasifikasi penilaian formatif dan sumatif seharusnya ditempatkan secara proposional dan saling melengkapi. Penilaian sumatif tepat untuk mendapatkan informasi tentang ketercapaian kompetensi keluaran; penilaian formatif tepat untuk mengidentifikasi area pembelajaran yang perlu diperbaiki atau ditingkatkan. Eckhout menegaskan bahwa "good teaching is impossible in the absense of good assessment"2. Mutu pembelajaran ditentukan oleh mutu penilaian yang digunakan di dalam kelas 3 . Penilaian proses merupakan instrumen yang adekuat untuk mencapai tujuan pendidikan melalui perbaikan pembelajaran yang berkelanjutan.

Penilaian formatif merupakan penilaian interaktif dalam proses pembelajaran untuk perbaikan pembelajaran melalui pemanfaatan informasi tentang proses dan hasil belajar siswa. Popham (2008) mendefinisikan sebagai proses yang digunakan guru dan siswa dalam proses pembelajaran untuk memberikan umpan balik bagi perbaikan

${ }^{2}$ Eckhout, T. J., Davis, S. L., Mickelson, Kristine \& Goodburn, Amy A method for providing assessment training to in-service and pre-service teacher, paper, the annual meeting of the Southwestern Educational Research Association. New Orleans, LA, 2005. 3.

${ }^{3}$ Stiggins, R. Are you assessment literate? The High School Journal (1999, 6, 5) 
pembelajaran dan peningkatan hasil belajar yang telah ditetapkan. Penilaian yang efektif menggunakan berbagai teknik untuk memperoleh informasi yang kaya dan relevan. Penilaian formatif mengkombinasikan tugas, instrumen dan proses ${ }^{4}$. Interpretasi data-data tersebut digunakan guru (dan siswa) untuk menentukan posisi siswa dalam pembelajarannya, kemana siswa perlu melangkah dan bagaimana cara terbaik untuk mencapainya. Interaksi guru dan siswa dimediasi melalui umpan balik -sebagai prinsip pokok penilaian formatif. Umpan balik adalah metode efektif untuk meningkatkan hasil belajar. Marzano menegaskan "the most powerful single modification that enhances achievement is feedback" 5 . Black dan William mengidentifikasi lima faktor kunci yang dapat meningkatkan pembelajaran melalui penilaian, yaitu' memberikan umpan balik yang efektif, melibatkan siswa secara aktif dalam pembelajaran, mengelola pembelajaran yang memungkinkan siswa memperoleh nilai baik ketika dilakukan penilaian, menjelaskan keterkaitan antara penilaian, motivasi dan self-esteem dan

${ }^{4}$ Boyle, B., \& Charles, M. Formative assessment for teaching and learning. (Thousand Oaks, CA: SAGE Publications Inc. 2013)

${ }^{5}$ Hammerman, E. Formative assessment strategies for enhanced learning in science, K-8. (Thousand Oaks, CA: Corwin Press, 2009), 9.

${ }^{6}$ Chappuis, S. Assessment for learning: An action guide for school leaders. Portland, (OR: Assessment Training Institute, 2004) 
mempertimbangkan konteks (dan kebutuhan) siswa untuk melakukan penilaian diri dan memfasilitasi peningkatan belajarnya.

Assessment Reform Group dan Suratno memaparkan prinsipprinsip utama penilaian formatif. Pertama, penilaian formatif merupakan bagian dari pembelajaran yang efektif; Kedua, penilaian formatif memfokuskan pada cara belajar siswa, yang merupakan inti proses pembelajaran sekaligus kunci utama profesionalitas guru; Ketiga, mempertimbangkan aspek sensitivitas dan umpan balik yang konstruktif; Keempat, penilaian formatif menekankan pada peningkatan motivasi belajar siswa serta pengembangan kapasitas penilaian diri (reflektif); Kelima, penilaian formatif ditujukan untuk mencapai tujuan pendidikan secara holistik. Strategi dasar yang dapat diterapkan dalam kerangka itu adalah bertanya, umpan balik melalui komentar, penilaian diri dan penilaian sejawat, serta menjadikan penilaian sumatif sebagai penilaian formatif.

Pembelajaran yang efektif dan penilaian yang bermutu merupakan kegiatan belajar yang berkelanjutan. Praktik ini memfokuskan pada proses kognitif dan/atau metakognitif. Proses kognitif mencakup pemahaman mendalam tentang penilaian dan pemanfaatan data penilaian dengan cara baru; berpikir secara sistematis, integratif dan holistik; serta menjelaskan relasi antar aspek yang dikaji 
hal ini disampaikan oleh McMillan. Proses metakognitif terjadi ketika guru atau siswa menyadari apa yang dipelajari, dan menggunakan informasi yang ditemukan untuk melakukan penyesuaian, bahkan perubahan mendasar pada praktik mengajar atau cara belajarnya. Metakognitif didefinisikan sebagai "thinking about thinking". Flavell mendefinisikan sebagai "knowledge about cognition and control of cognition". Ketika guru merefleksi argumen tindakan pengajarannya, dan siswa menilai proses dan hasil belajarnya merupakan hal kritis bagi penilaian sebagai pembelajaran.

Menurut Lorna proses kognitif siswa terjadi saat siswa berinteraksi dengan materi atau pengalaman baru untuk membentuk pengetahuan baru. Siswa adalah aktor aktif belajarnya, mampu menilai belajarnya (self-assessment) dan kompeten dalam menyerap informasi Siswa secara aktif memahami, menciptakan makna dan mengadaptasi pemikirannya ketika memperoleh informasi baru. Proses tersebut menurut McMillan - mencakup enam langkah7: menjelaskan, menafsirkan, menerapkan, pengajukan perspektif, berempati dan sadar diri (self-knowing). Sedangkan Pintrich mengemukakan bahwa proses kognitif mencakup pengetahuan tentang aspek strategi belajar, tugas

${ }^{7}$ McMillan, J. H. (2007). Classroom assessment: Principles and practice for effective standards based instruction, ed. 4. Boston, MA: Pearson Education, Inc. Junaidi \& Taufiqurrahman | 46 gurnal Pengabdian Masyarakat 
dan tentang-diri. Aspek strategi mencakup pengetahuan tentang cara yang digunakan dalam belajar, berpikir dan penyelesaian masalah; Aspek tugas mencakup pengetahuan tentang tingkat kesulitan suatu tugas; Aspek tentang-diri mencakup pengetahuan tentang kekuatan dan kelemahan serta motivasi diri, termasuk self-efficacy dan minat pada topik yang dibahas. Pengetahuan tentang diri ini menunjukkan apa yang diketahui dan tidak diketahui oleh siswa dan langkah apa yang dibutuhkan untuk menyelesaikan tugas ${ }^{8}$.

Kemampuan metakognisi siswa adalah kekuatan untuk memberdayakan diri dengan memanfaatkan pengetahuan dan keterampilan untuk menyelesaikan masalah hidup dan kehidupannya (Earl, 2003) ${ }^{9}$, termasuk masalah-masalah dalam belajarnya. Guru, dalam pembelajaran yang berpusat pada siswa, tidak menggunakan penilaian untuk menghakimi, tetapi mengarahkan siswa untuk melakukan penilaian dalam proses pembelajaran melalui umpan balik dan dialog. Jordan menyebutnya sebagai “congitive extension". Praktik penilaian ini merupakan tindakan pemberdayaan; Siswa mengajukan pertanyaan reflektif, memilih learning style yang sesuai dan strategi bertindak yang

8 Pintrich, P. R. The role of metacognitive knowledge in learning, teaching, and assessing. Theory Into Practice, 2002, 41(4), 220-227.

${ }^{9}$ Earl, L. M. Assessment as learning: Using classroom assessment to maximize student learning. Thousand Oaks, CA: Corwin A SAGE Company. (2003). 
tepat. Sato menegaskan bahwa pemahaman akan diperkuat ketika siswa menjelaskan apa yang mereka pelajari dan bagaimana mereka belajar melalui penggunaan refleksi.

Penilain diri siswa tentang belajarnya dikonfirmasi oleh guru melalui umpan balik. Feedback merupakan jalinan konseptual antara apa yang dipahami siswa dengan kebijaksanaan yang tertulis dalam teks-teks, pengetahuan guru dan sumber lain sebagai rujukan bagi siswa. Umpan balik yang diberikan guru dapat mendorong siswa berupaya dan menggunakan berbagai metode alternatif untuk memperoleh pemahaman lebih mendalam. Peran guru, menurut Earl (2003: 90) adalah "to provide the kind of feedback to student that encourages their learning and provides signposts and directions along the way, bringging them closer to independence"10. Umpan balik adalah bagian proses penilaian, bukan hasil penilaian. Umpan balik yang diberikan guru tentang pemahaman siswa -baik yang sesuai maupun yang tidak tepat, digunakan oleh siswa untuk menyesuaikan pemahamannya, memikirkan ulang ide-idenya, kemudian mengajukan konsepsi baru. Proses pemberian umpan balik ini bukan merupakan suatu langkah sekali jalan, tetapi tindakan berkelanjutan. Dialog tentang penilaian

${ }^{10}$ Earl, L. M. Assessment as learning: Using classroom assessment to maximize student learning. Thousand Oaks, CA: Corwin A SAGE Company. (2003). 
siswa diperluas bukan hanya antara guru dan siswa, tetapi dapat pula terjadi antar siswa (penilaian sejawat). "It is part of a continuous conversation between teachers and students and among students"11.

Menurut Sawyer interaksi guru dan siswa melalui umpan balik dan dialog dipandang sebagai proses peningkatan secara bertahap. Proses ini sejalan dengan pandangan psikologi perkembangan terutama konsep scaffolding, yaitu bantuan yang diberikan selama proses pembelajaran, yang ditujukan untuk membantu pencapaian target belajar siswa Psikologi kognitif menyumbangkan teori cognitive load untuk menunjukkan jumlah total proses mental yang digunakan dalam memori kerja. Kelebihan beban informasi dapat dihindari dengan segmentasi materi sehingga siswa dapat mengelola dengan lebih baik proses belajarnya dikutip dari Clark dan Mayer. Teori ini menegaskan bahwa desain pembelajaran dapat digunakan untuk mengurangi beban kognitif siswa. Menurut Sweller "designed to provide guidelines intended to assist in the presentation of information in a manner that encourages learner activities that optimize intellectual performance". Segmentasi materi -yang termaktub dalam silabus, otonomi dan kemandirian, tindakan reflektif aktor pembelajaran, dan dialog yang konstruktif merupakan pilar

${ }^{11}$ Earl, L. M. Assessment as learning: Using classroom assessment to maximize student learning. Thousand Oaks, CA: Corwin A SAGE Company. (2003). 
penilaian sebagai pembelajaran untuk meningkatkan mutu pembelajaran.

Penerapan pilar-pilar tersebut, tentu saja, didokumentasikan melalui pengembangan dan penggunaan instrumen yang relevan, dan diolah untuk perbaikan pembelajaran secara berkelanjutan.Instrumen pokok penilaian dalam pembelajaran yang berpusat kepada siswa adalah rubrik dan catatan observasi atau anekdot. Rubrik dalam pendidikan dimaknai sebagai "scoring guide used to evaluate the quality of student's constructed responses"12. Efektivitas rubrik dilihat dari dua hal, yaitu kriteria tentang kinerja siswa dan paparan yang jelas tentang rentang mutu kinerja Catatan anekdot adalah dokumen pengamatan tentang perilaku siswa dalam proses pembelajaran. Anekdot ditulis dengan rinci, tanpa memberikan penilaian ${ }^{13}$.

Penelitian Black dan William menyimpulkan bahwa cara terbaik untuk meningkatkan hasil belajar adalah peningkatan penilaian kelas. Mereka merekomendasikan tiga hal, yaitu ${ }^{14}$ : meningkatkan kualitas dan akurasi penilaian ruang kelas, meningkatkan umpan balik deskriptif

${ }^{12}$ Popham, W. J. Assessment for educational leaders. Boston, MA: Allyn and Bacon. (2006), 238.

${ }^{13}$ Chappuis, S. Assessment for learning: An action guide for school leaders. Portland, (OR: Assessment Training Institute 2004), 84.

${ }^{14}$ Chappuis, S. Assessment for learning: An action guide for school leaders. Portland, (OR: Assessment Training Institute 2004) 
dan meningkatkan keterlibatan siswa dalam penilaian. Lebih lanjut, guru dan siswa harus mampu menjawab tiga pertanyaan tentang belajar siswa: kemana saya akan pergi? (pembelajaran yang dituntun oleh standar, yang dikomunikasikan dengan jelas kepada siswa); dimana saya sekarang? (umpan balik deskriptif dari guru kepada siswa tentang pencapaian belajarnya dan penilaian diri siswa tentang pencapaian belajarnya); bagaimana saya akan sampai kesana? (rancangan strategi pembelajaran yang didasarkan pada data tentang hasil belajar siswa kaitannya dengan standar dan strategi siswa untuk meningkatkan hasil belajarnya.

\section{Pelaksanaan Pengabdian}

\section{Gambaran Pelaksanaan}

Pelaksanaan pendampingan di awali dengan prosedur administrasi. Proses ini dilakukan untuk mendapatkan akses terhadap warga sekolah secara legal. Penerimaan sekolah terhadap pihak eksternal secara administratif merupakan langkah untuk membangun hubungan yang lebih intensif dan personal terhadap warga sekolah, serta mengetahui secara lebih mendalam kondisi sekolah. 


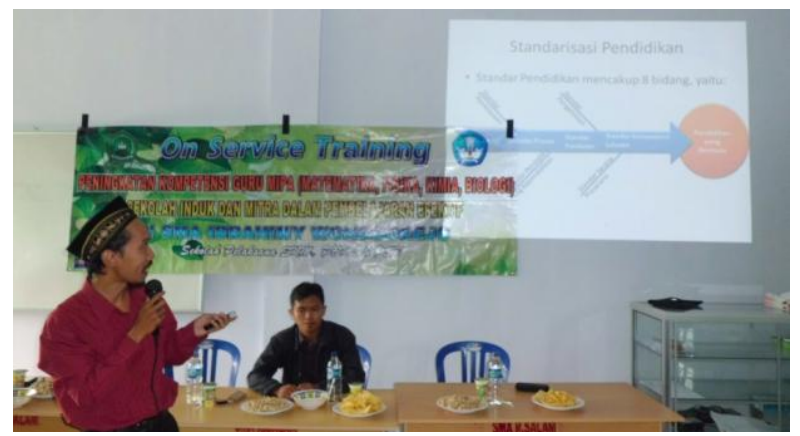

Suasana Diskusi dalam salah satu kegiatan pendampingan

Langkah selanjutnya adalah membangun hubungan atau komunikasi yang kurang formal. Situasi yang lebih akrab dilakukan untuk membangun kepercayaan kepada dari subyek dampingan. Komunikasi awal dilakukan terhadap guru-guru muda dan administrator sekolah. Proses komunikasi dilakukan pada warga senggang dan di tempat yang kurang formal, seperti kantin sekolah atau di luar gedung.

Perbincangan strategis pada saat proses pembangunan human relation digunakan untuk menggali informasi tentang kesulitan yang dihadapi warga sekolah dan harapan-harapan yang diinginkan serta auto-kritik subyek dampingan tentang praktiknya.

Perbincangan strategis pada tingkat individu selanjutnya diperluas dengan melibatkan berbagai subyek dalam format kegiatan yang lebih formal. Usai jam pelajaran sekolah dilakukan pertemuan 
dengan subyek yang berhubungan dengan masalah yang sedang dikaji. Proses ini ditujukan untuk menemukan persoalan bersama yang dihadapi oleh warga sekolah. Proses ini difasilitasi oleh pendamping. Hasil dari kegiatan ini agenda kerja selanjutnya untuk memetakan masalah-masalah secara lebih sistematis.

Pada tahap selanjutnya, pendamping mengajak warga sekolah untuk memetakan atau mengklasifikasi masalah yang dihadapi untuk menentukan masalah pokok yang akan dihadapi. Masalah disusun berdasarkan klasifikasi yang merujuk pada standar nasional pendidikan, dan diurut secara hirarkis berdasarkan nalar sebab-akibat. Teknik yang digunakan dalam proses ini adalah pohon masalah. Teknik ini memberikan tampilan masalah secara hirarkis dan diuji dengan nalar sebab-akibat. Hasil akhir penggunaan teknik ini adalah masalah pokok yang dihadapi oleh warga sekolah.Penentuan pokok masalah ini dihasilkan melalui permufakatan.

Pokok masalah yang ditemukan pada tahap sebelumnya merupakan kondisi negatif yang akan ditransformasikan menjadi situasi yang diharapkan. Teknik transformasi situasi ini adalah dengan melanjutkan menuliskan pernyataan positif yang disepakati sebagai penyelesaian masalah pokok. Penyelesaian ini kemudian dijabarkan melalui prasyarat-prasyarat yang dibutuhkan untuk mewujudkan 
kondisi yang diharapkan. Dalam memilih prasyarat kondisi tersebut memperhatikan sub pokok masalah yang telah dituliskan pada tahap sebelumnya. Dengan kata lain, pengembangan strategi tindakan secara detil adalah penyelesaian masalah-masalah spesifik sebagai prasyarat keberhasilan penyelesaian masalah pokok.

\section{Dinamika Keilmuan}

Praktik yang dilakukan warga sekolah berkaitan dengan pengembangan instrumen penilaian diperoleh dari berbagai sumber dan pengalaman. Pengetahuan teoritis yang melekat pada diri pendamping digunakan untuk memetakan atau mengkerangkakan tacit knowledge yang telah menjadi bagian dari praktik subyek dampingan.

Pengembangan instrument penilaian dalam bentuk pilihan ganda telah dipahami oleh subyek dampingan. Penjabaran Kompetensi Dasar menjadi indikator, penyusunan kisi-kisi soal, penulisan kartu soal dan butir soal pilihan ganda dapat dilakukan secara partisipatif oleh subyek dampingan. Namun, penyesuaian penulisan butir soal dengan kaidahkaidah masih membutuhkan fasilitasi dari pendamping.

Penulisan instrumen soal uraian pun masih membutuhkan fasilitasi dalam dua hal: ketaatan terhadap kaidah penulisan butir soal dan pedoman penskoran jawaban uraian. Sebelumnya, penskoran terhadap soal uraian dilakukan secara subyektif atau dipersepsi sebagai 
'kunci jawaban', artinya guru menuliskan satu rangkaian kalimat yang merupakan jawaban dari pertanyaan uraian. Pada tahap selanjutnya guru mempelajari penulisan pedoman penskoran.

Pada tes obyektif, guru telah dapat melakukan analisis terhadap tiga parameter: tingkat kesulitan, daya beda, dan pengecoh. Proses analisis yang dilakukan dengan menggunakan file kerja excel yang diperoleh dari pelatihan atau workshop yang diikuti oleh guru. Namun guru kesulitan untuk (1) membuktikan secara statistik bahwa item tertentu dapat mengukur kemampuan siswa; dan (2) membuktikan keajegan (reliabilitas) alat ukur (tes) yang dikembangkan. Untuk mengatasi hal tersebut guru secara kolaboratif menyusun file kerja excel untuk menyelesaikan masalah tersebut, diikuti oleh petunjuk penggunaannya.

Penyusunan instrument penilaian praktik dan penilaian diri terasa masih asing bagi guru. Namun, modal pengetahuan penelitian yang pernah dilakukan di waktu kuliah mengingatkan guru pada langkahlangkah penyusunan instrument penelitian, misalnya angket dan/atau lembar observasi. Pengetahuan tentang penyusunan instrumen penelitian ini kemudian secara kolaboratif dipanggil-ulang dalam konteks yang berbeda, yaitu penyusunan instrumen lembar observasi 
untuk ujian praktik, dan instrument penilaian diri dan penilaian sejawat dalam bentuk angket.

Terpaan informasi baru yang cukup banyak berkaitan dengan penyusunan instrumen-instrumen yang dikategorikan sebagai penilaian otentik. Paparan pengetahuan tentang penyusuan instrument penilaian portofolio, penilaian jurnal, dan penilaian proyek membutuhkan fasilitasi dari pendamping secara massif. Pada akhir kegiatan para guru sudah dapat mengkombinasikan pengetahuan teknis dengan pengetahuan kontekstual penggunaan alat ukur dan kondisi yang tepat.

\section{Teori yang dihasilkan dari pendampingan}

Berangkat dari keempat kesadaran itulah seharusnya seorang guru melakukan penilaian. Pendidik harus sudah tahu tujuan penilaian itu adalah mengukur kemampuan atau kompetensi siswa setelah dilaksanakannya proses pembelajaran. Setelah guru melakukan penilaian akan terlihat nanti kemampuan setiap siswa setelah guru melaksanakan test atau ujian dan kemudian melakukan penilaian.

Ketika guru telah memahami benar tujuan pembuatan soal yang sesuai dengan indikator dalam standar kompetensi (SK) dan kompetensi dasar (KD) yang harus dikuasai oleh siswa, maka guru yang bersangkutan akan dengan mudah membuat soal-soal test yang akan diujikan. Dari situlah guru melakukan bobot penilaian yang telah 
ditentukan lebih dahulu dalam Rencana Pelaksanaan Pembelajaran (RPP). Bila semua itu telah direncanakan dengan baik, maka tujuan pembelajaran akan tercapai. Hal ini terlihat dari prestasi siswa yang menggembirakan.

Dalam melakukan penilaian, seorang guru harus menyadari adanya sense of regulation (keteraturan). Guru harus membuat soal yang penuh dengan keteraturan dan sesuai dengan kisi-kisi soal yang telah dibuat sebelumnya. Ketika keteraturan telah menjadi kesadaran guru bahwa soal dibuat dalam rangka mengetahui kemampuan siswa, maka harus sesuai dengan aturan sekolah. Apakah dibuat dalam bentuk multiply chois atau berbentuk essay. Semua itu bergantung dari kesepakatan di antara sesama dewan guru dalam menentukan bentuk soal dan sistem penilaian yang diputuskan oleh pimpinan sekolah.

Penilaian yang dilakukan oleh guru harus mampu membuat setiap siswa berprestasi dan menemukan potensi unik yang dimiliki oleh setiap siswa. Akan terlihat nantinya, siswa mana yang unggul di bidang MIPA (matematika dan Ilmu Pengetahuan alam), olahraga, art (seni), dan lain sebagainya. Di sinilah peran guru yang memiliki kesadaran sense of achiement. Ketika terlihat ada siswa yang mengalami masalah dalam pembelajarannya, maka guru perlu melakukan Achievement Motivation Training (AMT) untuk memberikan 
motivasi dan semangat kepada siswa bahwa mereka sebenarnya bisa. Hanya mungkin faktor kemalasan yang membuat siswa yang bersangkutan mendapatkan nilai rendah. Setiap peserta didik adalah juara. Bila peserta didik mengalami kemalasan diri atau ada masalah dalam dirinya, maka guru harus menggali lebih jauh maslaah yang dihadapinya, lalu kemudian mencari solusinya agar peserta didik menjadi juara.

\section{Follow Up}

Setelah dilakukan pendampingan banyak apresiasi positif terhadap pelaksanaan pendampingan ke sekolah, ini sangat bermanfaat bagi guru dalam mencairkan masalah, dan kesulitan yang dialami guru terkait dengan instrumen penilaian, model pembelajaran dan cara penilaian. Ia berharap pendampingan ini berlanjut, sehingga membantu memecahkan persoalan yang dihadapi guru dan pihak sekolah.

Berdasarkan tingkat kebutuhan yang signifikan maka langkah pendampingan selanjutnya diarahkan kepada pengembangan

1. Perencanaan program sekolah dalam rangka mempersiapkan program Full Day School.

2. Analisis dan Pengembangan Kurikulum serta persiapan penerapan program kredit semester (SKS) 
3. Mengembangkan Program Pengelolaan Silabus, RPP dan Bahan Ajar dalam bentuk digital (e-learning)

4. Mengembangkan Rancangan Penilaian dan hasil belajar berbasis TIK dalam bentuk digital

\section{Kesimpulan}

Proses pendampingan di Sekolah Menengah Atas Ibrahimy Wongsorejo dilakukan dalam tahap-tahap: pemetaan awal, membangun hubungan dengan warga sekolah, pemetaan secara partisipatif, penentuan agenda dan pelaksanaan serta refleksi. Proses pendampingan ini dapat melakukan transformasi pengetahuan dan praktik. Transformasi dari pengetahuan yang lebih teknis menuju pengetahuan yang kontekstual.Artinya, penggunaan alat ukur penilaian digunakan sebagai dengan konteks belajar dan tujuan pendidikan; transformasi praktik penilaian dan perubahan perilaku pragmatis menuju perilaku sistematis.Artinya, guru telah secara terencana dan teratur mengelola prosedur pengumpulan dan pengelolaan penilaian untuk perbaikan pembelajaran dan pencapaian tujuan pendidikan nasional.

\section{Penutup}

Kegiatan pembelajaran sebaiknya ditutup dengan sesuatu yang menarik. Misalnya dengan membuat atau menarik kesimpulan, merefleksi kegiatan yang sudah dilakukan, umpan balik terhadap hasil 
penilaian, dan menyampaikan materi yang akan diberikan pada pertemuan yang akan datang. Pada umumnya guru lupa memberikan refleksi dari kegiatan yang sudah terjadi, umpan balik terhadap hasil belajar dan tidak menyampaikn materi yang akan datang.

Demikianlah temuan-temuan yang terjadi dilapangan, mudah-mudahan untuk kedepan kepala satuan pendidikan harus senantiasa memantau, mengamati dan membimbing para gurunya dalam upaya menjalankan setiap tahap pembelajaran dengan baik dan benar.

Untuk meningkatkan kompetensi guru, satuan pendidikan wajib memberikan pelatihan kepada guru-gurunya atau mengikutsertakan guru-guru dalam kegiatan kolektif di Musyawarah Guru Mata Pelajaran (MGMP).

\section{Daftar Pustata}

Boyle, B., \& Charles, M. Formative assessment for teaching and learning. Thousand Oaks, CA: SAGE Publications Inc. 2013.

Chappuis, S. Assessment for learning: An action guide for school leaders.

Portland, OR: Assessment Training Institute. 2004.

Chevalier, J.M. \& Buckles, D.J. Participatory Action Research: Theory and Methods for Engaged Inquiry, Routledge. 2013.

Curly, C. Pedagogoes for student-centered learning: Onlie and on-ground. 
Augsburg: Fortress Press. 2014.

Earl, L. M. Assessment as learning: Using classroom assessment to maximize student learning. Thousand Oaks, CA: Corwin A SAGE Company. 2003.

Eckhout, T. J., Davis, S. L., Mickelson, Kristine \& Goodburn, Amy A method for providing assessment training to in-service and preservice teacher, paper, the annual meeting of the Southwestern Educational Research Association. New Orleans, LA. 2005.

Hammerman, E. Formative assessment strategies for enhanced learning in science, K-8. Thousand Oaks, CA: Corwin Press. 2009.

Jahnke, I. A way out of the information jungle. Dalam Coakes, E. Technological change and societal growth: Analyzing the future. Hershey, PA: IGI Global. 2012.

Keengwe, J. \& Onchwari, G. Handbook of research on learner-centered pedagogy in teacher education. Hershey, PA: IGI Global. 2016.

Kusaeri. Acuan dan Teknik Penilaian Proses dan Hasil Belajar dalam Kurikulum 2013. Ar-Ruzz Media. 2005.

McMillan, J. H. Classroom assessment: Principles and practice for effective standards based instruction, ed. 4. Boston, MA: Pearson Education, Inc. 2007.

McTighe, J., \& O'Connor, K. Seven practice for effective learning, 
Educational Leadership, 63 (3). TT.

Pintrich, P. R. The role of metacognitive knowledge in learning, teaching, and assessing.Theory Into Practice, , 41(4), 2002.

Popham, W. J. Assessment for educational leaders. Boston, MA: Allyn and Bacon. 2006.

Popham, W. J. Transformative assessment. Denvers, MA: ASCD. 2008.

Reason, P. \& Bradbury, H. The Sage Handbook of Action Research: Participative Inquire and Practice. Thousand Oaks, CA: SAGE Publications Inc. 2008.

Stiggins, R. Are you assessment literate? The High School Journal, 6, 5, 1999.

Walvoord, B. E. Assessment clear and simple: A practical guide for institutions. San Francisco, CA: John Wiley \& Sons. 2004. 